\title{
Defensive behaviour in Rana graeca
}

\author{
DANIEL JABLONSKI ${ }^{*}$, ELIAS TZORAS ${ }^{2} \&$ PANAGIOTIS DRAKOPOULOS 3
}

${ }^{1}$ Department of Zoology, Comenius University in Bratislava, Ilkovičova 6, Mlynská dolina, 84215 Bratislava, Slovakia

2Patra, 26442 Achaia, Greece

${ }^{3}$ School of Forestry and Management of the Environment and Natural Resources, Demokritus University of Thrace, Athanasiou Pantazidou 193, 68200 Orestiada, Greece

*Corresponding author Email: daniel.jablonski@balcanica.cz

D efensive behaviours in frogs and toads have been well reviewed (e.g. Toledo et al., 2011; Jablonski \& Balej, 2014; Jablonski, 2017) indicating different families of amphibians are reported to show different types of defense against potential threats. This includes the Ranidae (Toledo et al., 2011; Carretero et al., 2011) and here we describe the first observation of defensive behaviour in Rana graeca. This species is endemic to the Balkan Peninsula ranging from Bosnia and Herzegovina through central and southern parts of the peninsula to eastern Bulgaria (Speybroeck et al., 2016). Except in distribution, only scattered information is known about this species.

On 12 October 2014 (near the village of Chora Getson, Peloponnese, Greece; $36.948^{\circ} \mathrm{N}, 22.254^{\circ} \mathrm{E}$, WGS84, $605 \mathrm{~m}$ elev.; Fig. 1A) and on 29 October 2018 (near the village of Krini, Peloponnese, Greece; $38.179^{\circ} \mathrm{N}, 21.749^{\circ} \mathrm{E}$, WGS84, 206 $\mathrm{m}$ elev.; Fig. 1B) we observed defensive behaviour known as "eye-protection" in three adult individuals of $R$. graeca. These individuals were captured from the surface of the water in a small stream. The animals were captured by hand around the noon and immediately took up the defensive posture after direct touch. They remained in this posture for up to 5 minutes. The individuals were released back to their habitat after photography. After release, they remained in this defensive posture for a few seconds until it reached the bottom of the stream and then moved normally. In all cases the eyes were open (Fig. 1). No defensive call was heard or defensive odour detected. During field work from spring to autumn the first author examined approximately 100 individuals of the species and recorded this behaviour only once.

This defensive behaviour is known in different members of the Ranidae as well as other families of amphibians (Toledo et al., 2011; Schlüpmann, 2000; Carretero et al., 2011) and it is hypothesised that the main function is protection of the eyes that could be damaged during possible regurgitation (Toledo et al., 2011). However, such explanation may be misleading and observed behaviour could be only a part of complex defensive mechanisms that are currently understudied. Similar behaviour is well known for the genus Bombina (unkenreflex) but is usually attributed to warning colouration of skin toxins when on land and to fish swimming below when floating on the surface (Jablonski

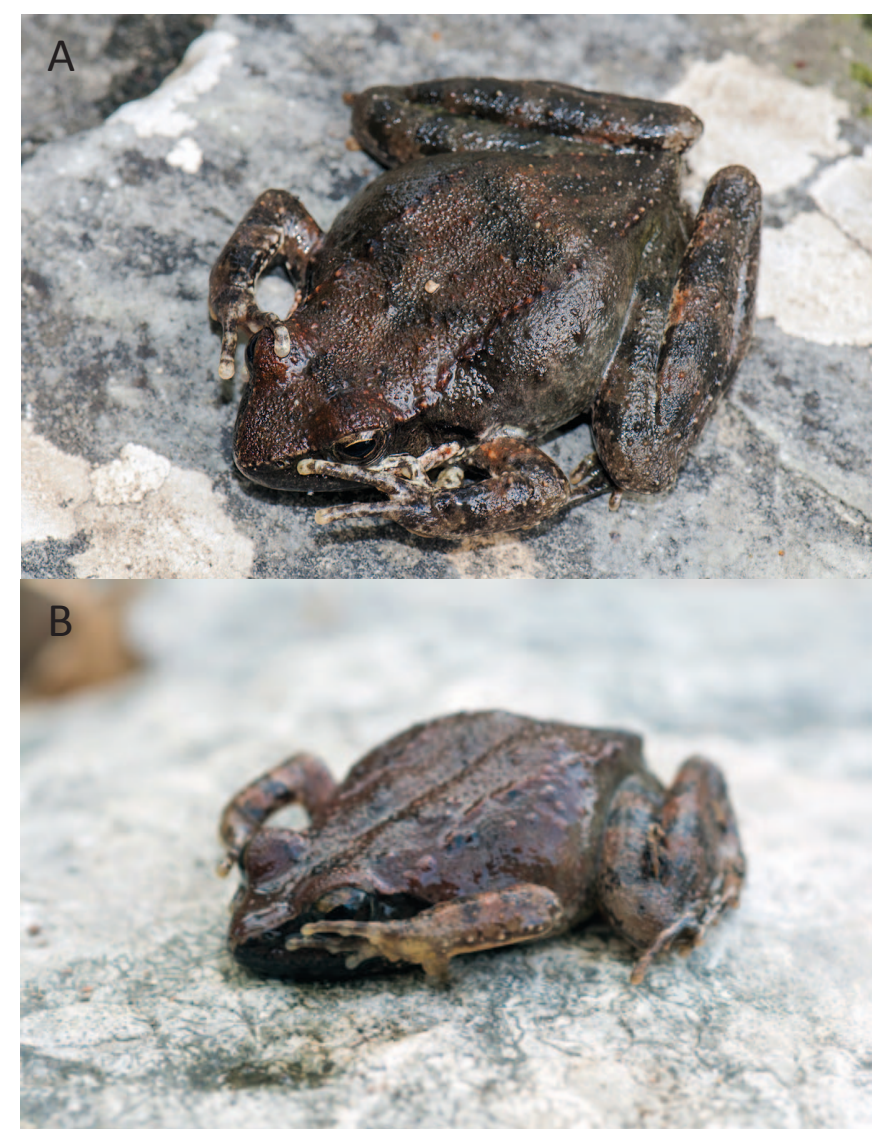

Figure 1. Individuals of $R$. graeca displaying defensive postureChora Getson (A), Krini (B)

\& Balej, 2014; Bordignon et al. 2018). The possibility that the posture would be of benefit if the individual was regurgitated seems improbable. Usually if an amphibian is swallowed, the head is the first (common for snake predators) before the front limbs which are forced backwards away from the eyes. During regurgitation they would be held in this position and unprotected. Hypothetically, this posture may i) make the individual appear more difficult to swallow (especially for snakes), ii) as a variant of thanatosis it could be an attempt to be inconspicuous to increase its survival (Brodie et al., 1998). Our observations as well as in the literature (e.g. Jablonski \& Gvoždík, 2009; Carretero et al., 2011) suggest the possibility 
that some Palaearctic frogs use this behaviour more often at lower temperature (depending on year, season, time of day, elevation etc.) when they are hypothermic. In this case (middle and late October), our observed individuals displayed slower reactions and adopted the observed behaviour defence instead of attempting to escape. The lower temperatures during autumn may play a role (Haberl \& Wilkinson, 1997), but do not have to be the core factor involved.

\section{ACKNOWLEDGMENTS}

We would like to thank two anonymous reviewers for their valuable comments. This study was supported by the Slovak Research and Development Agency under the contract no. APVV-15-0147.

\section{REFERENCES}

Bordignon, D., Caorsi, Z.V., Colombo, P., Abadie, M., Brack, I.V., Dasoler, B.T., Borges-Martins, M. (2018): Are the unken reflex and the aposematic colouration of RedBellied Toads efficient against bird predation? PLOS ONE 13: e0193551.

Brodie, E.D. Jr., Williams, C.R., Tyler M.J. (1998): Evolution of aposematic behavior and coloration in the Australian frog genus Uperoleia. Journal of Herpetology 32: 136139.
Carretero, M.A., Sillero, N., Corti, C., Jorge, F., Freitas, S., Arakelyan, M. (2011): Unkenreflex in Rana macrocnemis from Armenia. Herpetology Notes 4: 67-69.

Haberl, W., Wilkinson, J.W. (1997): A note on the Unkenreflex and similar defensive postures in Rana temporaria (Anura, Amphibia). British Herpetological Society Bulletin 61: 16-20.

Jablonski, D. (2017): Two types of defensive behavior recorded in Bufotes pewzowi (Bufonidae). Herpetological Bulletin 140: 40-41.

Jablonski, D., Balej, P. (2014): Case of defensive behavior in Pelobates syriacus (Amphibia: Pelobatidae). Herpetology Notes 7: 141-143.

Jablonski, D., Gvoždík, V. (2009): Imobilita jako obranné chování žab pozorované u skokana hnědého. Živa 57: 228-229.

Schlüpmann, M. (2000): Schreckruf und Unkenreflex beim Grasfrosch (Rana temporaria) sowie Anmerkungen zu Schreckreaktionen bei Amphibien. Zeitschrift für Feldherpetologie 7: 29-35.

Speybroeck, J., Beukema, W., Bok, B., Van Der Voort, J., Velikov, I. (2016): Field Guide to the Amphibians and Reptiles of Britain and Europe. Bloomsbury Publishing. $432 \mathrm{pp}$.

Toledo, L.F., Sazima, I., Haddad, C.F.B. (2011): Behavioural defences of anurans: an overview. Ethology Ecology \& Evolution 23: 1-25. 